with the more severe and, possibly, progressive lung changes. This suggests the possibility that the presence of antibodies is either related in some indirect way to pathogenesis or results from tissue damage. On the other hand, the presence of quite severe lung changes without antibodies suggests that they are neither directly responsible for the lung changes nor are they likely to result non-specifically from lung destruction. The absence of A.N.F. and rheumatoid factor in many other types of chronic fibrosing lung disease, including chronic farmer's lung, chronic bird-breeder's lung, and sarcoidosis (TurnerWarwick and Haslam, unpublished), is supporting evidence that these autoantibodies do not occur as a result of lung damage alone.

Possibly circulating antibody and cellular hypersensitivity together initiate lung damage analogous to experimental allergic orchitis (Holborow and Johnson, 1965); this is now being investigated. Alternatively, circulating autoantibodies may in some other way enhance tissue damage caused by asbestos dust. Another explanation for the increased prevalence of circulating antibodies is that, for some reason at present unknown those members of the general population with a genetic tendency to produce antiglobulin and antinuclear factors may react in an abnormal way to inhalation of asbestos or to the inflammatory response it provokes, and are therefore selected out into the group of exposed subjects developing lung changes. A further survey is now in progress to study the incidence of tissue antibodies in large numbers of asbestos workers with and without evidence of lung disease. A similar selection process has been suggested to account for the increased prevalence of rheumatoid factor in certain categories of coal miners' pneumoconiosis (Lindars and Davies, 1967). If this theory proves correct then screening for circulating antinuclear and antiglobulin factors before acceptance into any industry with an asbestos hazard might form a basis for excluding from risk those with unusual susceptibility.

We should like to thank Mrs. Haslam and Mrs. Weeks for technical assistance, and Mrs. N. Murray for her help with co-ordination of the study. We are also grateful to the Asbestos Research Council, the Chest and Heart Association, and the Medical Research Council for their generous support; and to Dr. J. Watkins Pitchford, chief medical officer in the Department of Health and Social Security, for permission to publish. We should also like to thank Dr. A. Caplan for his interest in the work.

\section{REFERENCES}

Ball J., and Lawrence, J. S. (1961). Annals of the Rheumatic Diseases, 20, 235. Barnett, E. V., Leddy, J. P., Condemi, J. J., and Vaughan, J. H. (1965). Annals of the New York Academy of Sciences, 124, 896.

Beck, J. S. (1963). Scottish Medical fournal, 8, 373.

Brown, P. C., Glynn, L. E., and Holborow, E. J. (1967). Immunology, 13, 307 Brown, P. C., Glynn, L. E., and Holt

Caplan, A., Payne, R. B., and Withey, J. L. (1962). Thorax, 17, 205.

Coons, A. H., and Kaplan, M. H. (1950). Fournal of Experimental Medicine, 91, 1 .

Holborow, E. J., and Johnson, G. D. (1965). Annals of the New York Academy of Sciences, 124, 833.

International Labour Office (1959). Occupational Safety and Health 9, 2.

Liddell, F. D. K. (1963). British Fournal of Industrial Medicine, 20, 300.

Lindars, D. C., and Davies, D. (1967). Thorax, 22, 525.

Morgan, W. K. C. (1964). Thorax, 19, 433.

Nice, C. M., and Ostrolenk, D. G. (1968). Diseases of the Chest, 54, 226 Pernis, B., and Vigliani, E. C. (1965). Annals of the New York Academy of Sciences, 132, 112

Rickards, A. G., and Barrett, G. M. (1958). Thorax, 13, 185.

Rose, H. M., Ragan, C., Pearce, E., and Lipman, M. O. (1948). Proceedings of the Society of Experimental Biology and Medicine, 68, 1 .

Singer, J. M., and Plotz, C. M. (1956). American fournal of Medicine, 21, 888. Solomon, A. (1969). South African Medical fournal, 43, 847

Tellesson, W. B. (1961). Thorax, 16, 372.

Turner-Warwick, M., and Doniach, D. (1965). British Medical fournal, 1, 886 .

\title{
Sulphadimidine Acetylation Test for Classification of Patients as Slow or Rapid Inactivators of Isoniazid
}

\author{
K. V. N. RAO,* D.SC. ; D. A. MITCHISON†, M.B., M.R.C.P., M.R.C.PATH. ; N. G. K. NAIR, $\ddagger$ M.SC. \\ K. PREMA, $\$ M.SC. ; S. P. TRIPATHY, $\|$ M.D.
}

British Medical fournal, 1970, 3, 495-497

\begin{abstract}
Cummary: Sulphadimidine acetylation studies were un$S$ dertaken in 103 patients, 52 of whom had been classified as slow and 51 as rapid inactivators of isoniazid by a standard microbiological assay method. Each patient received sulphadimidine by mouth in a dose of 44 $\mathrm{mg} / \mathrm{kg}$. body weight, and free and total sulphadimidine were estimated in blood and urine collected at six hours. The findings suggest that patients may be classified as slow inactivators of isoniazid if the proportion of acetylated sulphadimidine (total minus free) is (a) less than $25 \%$ in blood or (b) less than $70 \%$ in urine. The sulphadimidine test is easy to perform and the result is available the same day; urine specimens for the test can be stored at room temperature for over a week without any loss of drug.
\end{abstract}

- Formerly Senior Research Officer (Biochemistry), Tuberculosis Chemotherapy Centre, Madras 31. Present address: W-615, Department of Medicine, University of Chicago, Chicago, Ill., U.S.A

† Director, M.R.C. Unit for Laboratory Studies of Tuberculosis, and Professor of Bacteriology, Royal Postgraduate Medical School, London W.12.

\# Assistant Research Officer (Statistics), Tuberculosis Chemotherapy Centre, Madras 31.

$\checkmark$ Assistant Research Officer (Biochemistry), Tuberculosis Chemotherapy Centre, Madras 31.

|| Director, Tuberculosis Chemotherapy Centre, Madras 31.

\section{Introduction}

Several investigators have shown that the rate of inactivation of isoniazid depends on the rate of its acetylation (Evans and White, 1964; Peters, Miller, and Brown, 1965), and that individuals can be broadly classified as slow or rapid inactivators (Knight, Selin, and Harris, 1959; Evans, Manley, and McKusick, 1960; Jenne, 1960; Sunahara, Urano, and Ogawa, 1961). Until recently the determination of the rate of inactivation had little practical value in the chemotherapy of pulmonary tuberculosis, since the rate was of little or no prognostic importance with daily regimens (Harris, 1959, 1961; Selkon et al., 1961; Schmidt, 1962; Scottish Thoracic Society, 1962; Tuberculosis Chemotherapy Centre, Madras, 1963). With the advent of intermittent regimens, however, the determination of the isoniazid inactivation rate acquired much practical importance. For instance, a recent study from this centre showed that the response of rapid inactivators of isoniazid to once-weekly regimens of chemotherapy is substantially inferior to that of slow inactivators (Menon, 1968; Tuberculosis Chemotherapy Ventre, Madras, 1970).

The rate of inactivation of isoniazid is usually determined by estimating the concentration of free isoniazid in the serum (by microbiological or chemical methods) at a specified time after a test dose of the drug. However, the need for collecting 
blood from the patients, the instability of isoniazid in serum during transport (Poole and Meyer, 1960; Jenne, 1961), and the complexity of current procedures of estimation often render determination of the isoniazid inactivation rate impracticable. Thus there is a need for a relatively simple procedure.

Both isoniazid and sulphadimidine are acetylated in the liver by similar enzymatic processes (Evans and White, 1964), and the rate of acetylation of isoniazid closely parallels that of sulphadimidine (Evans and White, 1964; Peters, Gordon, and Brown, 1965). Indeed, the determination of the sulphadimidine acetylation rate on liver biopsy specimens has been successfully employed for the routine classification of isoniazid inactivation phenotypes in man (Evans, 1965). The results are reported here of a sulphadimidine acetylation test in urine and blood specimens to classify patients as slow or rapid inactivators of isoniazid.

\section{Materials and Methods}

The investigations were undertaken in patients admitted to a chemotherapy study at this centre.

Rate of Inactivation of Isoniazid.-The concentration of isoniazid in serum four and a half hours after an intramuscular test dose of $3 \mathrm{mg} . / \mathrm{kg}$. body weight was determined by microbiological assay, using a vertical diffusion method similar to that described by Lloyd and Mitchison (1964). Patients with concentrations of $0.63 \mu \mathrm{g} . / \mathrm{ml}$. or more were classified as slow inactivators of isoniazid, and those with concentrations of less than $0.63 \mu \mathrm{g} . / \mathrm{ml}$. as rapid inactivators (Tuberculosis Chemotherapy Centre, Madras, 1970).

Acetylation of Sulphadimidine.-Pure sulphadimidine (sulphadimethylpyrimidine, sulphamethazine) in a dose of 44 $\mathrm{mg}$. $/ \mathrm{kg}$. body weight-that is, $2 \mathrm{~g}$. for a $100 \mathrm{lb}$. (45.4 kg.) patient-was given by mouth as a fine suspension in water. Antituberculosis drugs were withheld for at least two days before the test, and, as a check, a urine specimen was collected before administration of sulphadimidine and tested for acetylisoniazid (Eidus and Hamilton, 1964) and for aromatic amines by diazotization and final reaction with $\mathrm{N}-(1-$ naphthyl) ethylenediaminedihydrochloride. Estimations of free and total sulphadimidine in blood and urine were undertaken by a micro-method based on the Bratton and Marshall technique (Varley, 1962), and the acetylated sulphadimidine (total minus free) was expressed as a percentage of the total sulphadimidine for purposes of analysis.

\section{Results}

Timing of Collection of Blood and Urine Specimens.-In order to determine the optimal timings for the collection of blood and urine specimens a preliminary study was undertaken in 10 patients, five of whom were known by the vertical diffusion method to be slow inactivators of isoniazid, and the other five to be rapid inactivators. In this investiga- tion blood was drawn at 3,6, 9, and 24 hours after the test dose, the total urine excreted during $0-3,3-6$, and 6-9 hours was collected, and a urine specimen was obtained at 24 hours. The findings are presented in Table I. An examination of the individual percentages and the $t$ values in the last column indicates that the discrimination between slow and rapid inactivators was (a) most efficient with the 9-hour blood specimen and the 6-9-hour urine collection, (b) less efficient but nevertheless highly satisfactory with the 6-hour blood specimen and the 3-6 hour urine collection, and (c) much less efficient with the other measures. On the basis of these results, and for convenience in organization, it was decided that both blood and urine should be collected at 6 hours in the main study to be described below. Furthermore, to increase the discriminative ability of the test on urine it was decided that the patient should be asked to empty the bladder at 5 hours and then drink a cup of water. The results of the main study, conducted on 52 known slow inactivators of isoniazid and 51 known rapid inactivators, are presented below.

Acetylated Sulphadimidine in Blood.-The distributions of slow and rapid inactivators of isoniazid, according to the percentage of acetylated sulphadimidine in blood at six hours, are illustrated in the upper half of the Chart and summarized in the upper half of Table II. Less than $25 \%$ of sulphadimidine was acetylated by 51 of 52 slow inactivators, and $26 \%$ by the remaining patient. In contrast, $25 \%$ or more was acetylated by 49 of 51 rapid inactivators, and 12 and $23 \%$ by the remaining two patients. These findings suggest that a patient may be classified as a slow inactivator of isoniazid if

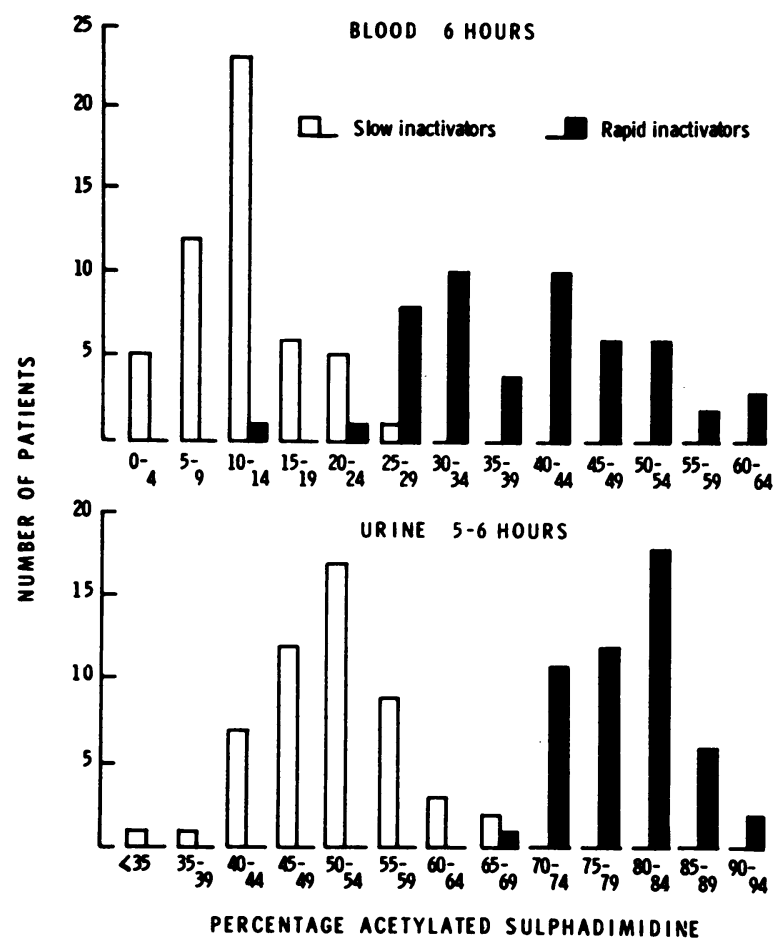

TABLE I.-Acetylation of Sulphadimidine After an Oral Dose of $44 \mathrm{mg} . / \mathrm{kg}$. Body Weight in Five Slow and Five Rapid Inactivators of Isoniazid

\begin{tabular}{|c|c|c|c|c|c|c|c|c|c|c|c|c|c|c|c|c|c|c|c|c|}
\hline & & & & & & & \multirow{3}{*}{$\begin{array}{l}\text { Hours or } \\
\text { Period after } \\
\text { Test Dose }\end{array}$} & \multicolumn{12}{|c|}{ Acetylated Sulphadimidine* } & \multirow{3}{*}{$\begin{array}{l}\text { Measure of } \\
\text { Discrimin - } \\
\text { ation } \\
t \neq\end{array}$} \\
\hline & & & & & & & & \multicolumn{5}{|c|}{ Slow I nactivators $\dagger$} & \multicolumn{5}{|c|}{ Rapid Inactivators } & \multirow{2}{*}{\begin{tabular}{|c|} 
Mean for \\
Slow \\
Inactivators
\end{tabular}} & \multirow{2}{*}{\begin{tabular}{|c|} 
Mean for \\
Rapid \\
Inactivators
\end{tabular}} & \\
\hline & & & & & & & & A & B & C & $\mathrm{D}$ & $\mathrm{E}$ & $\mathbf{P}$ & Q & $\mathbf{R}$ & $s$ & $T$ & & & \\
\hline Blood & .. & .. & $\cdots$ & .. & .. & & $\begin{array}{r}3 \\
6 \\
9 \\
24\end{array}$ & $\begin{array}{l}14 \\
12 \\
22 \\
18\end{array}$ & $\begin{array}{r}4 \\
3 \\
11 \\
14\end{array}$ & $\begin{array}{r}12 \\
12 \\
28 \\
28\end{array}$ & $\begin{array}{r}10 \\
15 \\
24 \\
11\end{array}$ & $\begin{array}{r}5 \\
12 \\
16 \\
30\end{array}$ & $\begin{array}{r}35 \\
46 \\
48 \\
0\end{array}$ & $\begin{array}{l}28 \\
35 \\
45 \\
33\end{array}$ & \begin{tabular}{|l|}
60 \\
73 \\
70 \\
22
\end{tabular} & $\begin{array}{l}31 \\
47 \\
52 \\
25\end{array}$ & $\begin{array}{l}22 \\
46 \\
60 \\
25\end{array}$ & $\begin{array}{r}6 \\
11 \\
18 \\
20\end{array}$ & $\begin{array}{l}35 \\
49 \\
55 \\
21\end{array}$ & $\begin{array}{l}4 \cdot 13 \\
5.83 \\
7.32 \\
0.12\end{array}$ \\
\hline Urine & & & .. & .. & .. & .. & $\begin{array}{r}0-3 \\
3-6 \\
6-9 \\
24\end{array}$ & $\begin{array}{l}20 \\
41 \\
43 \\
58\end{array}$ & $\begin{array}{l}39 \\
42 \\
46 \\
51\end{array}$ & $\begin{array}{l}53 \\
50 \\
55 \\
59\end{array}$ & $\begin{array}{r}41 \\
42 \\
48 \\
0\end{array}$ & $\begin{array}{r}30 \\
40 \\
50 \\
0\end{array}$ & $\begin{array}{r}73 \\
80 \\
80 \\
100\end{array}$ & $\begin{array}{l}84 \\
90 \\
94 \\
96\end{array}$ & $\begin{array}{l}78 \\
77 \\
82 \\
90\end{array}$ & $\begin{array}{l}70 \\
67 \\
78 \\
50\end{array}$ & $\begin{array}{l}37 \\
66 \\
79 \\
87\end{array}$ & $\begin{array}{l}37 \\
43 \\
48 \\
34\end{array}$ & $\begin{array}{l}68 \\
76 \\
83 \\
85\end{array}$ & $\begin{array}{l}3.21 \\
6.90 \\
9 \cdot 63 \\
3 \cdot 10\end{array}$ \\
\hline
\end{tabular}


TABLB II.-Distributions of Slow and Rapid Inactivators of Isoniazid According to Percentage of Acetylated Sulphadimidine in Blood and Urine

\begin{tabular}{|c|c|c|c|c|}
\hline & & \multirow{2}{*}{$\begin{array}{l}\text { Acetylated } \\
\text { Sulphadimidine* }\end{array}$} & \multicolumn{2}{|c|}{$\begin{array}{l}\text { Classification Based on } \\
\text { Microbiological Assay } \\
\text { of Isoniazid }\end{array}$} \\
\hline & & & $\begin{array}{c}\text { Slow } \\
\text { Inactivator }\end{array}$ & $\begin{array}{c}\text { Rapid } \\
\text { Inactivator }\end{array}$ \\
\hline Blood (at 6 hours) & .. & $\begin{array}{l}\text { Less than } 20 \\
20-24 \\
25-29 \\
30 \text { or more }\end{array}$ & $\begin{array}{r}46 \\
5 \\
1 \\
0\end{array}$ & $\begin{array}{r}1 \\
1 \\
81 \\
41\end{array}$ \\
\hline Urinet (5-6 hours) & .. & $\begin{array}{l}\text { Less than } 60 \\
60-64 \\
65-69 \\
70 \text { or more }\end{array}$ & $\begin{array}{r}47 \\
3 \\
2 \\
0\end{array}$ & $\begin{array}{r}0 \\
0 \\
1 \\
49\end{array}$ \\
\hline
\end{tabular}

-Expressed as a percentage of total-that is, acetylated plus free-sulphadimidine. tThe specimen was missed for one patient (rapid inactivator).

the percentage of acetylated sulphadimidine is less than 25 and as a rapid inactivator if it is 25 or more. By employing this classification rule, agreement with the classification based on the findings of microbiological assay of isoniazid was obtained in 100 of 103 patients. The three discrepancies appear to be due to misclassification by the blood sulphadimidine test, as the classification by the microbiological assay of isoniazid was confirmed in all three by the classification based on the percentage of acetylated sulphadimidine in urine (see below).

Acetylated Sulphadimidine in Urine.-The findings, illustrated in the lower half of the Chart and summarized in the lower half of Table II, suggest that a patient may be classified as a slow inactivator of isoniazid if the percentage of acetylated sulphadimidine in urine at 5-6 hours is less than $\mathbf{7 0}$, and as a rapid inactivator if it is $\mathbf{7 0}$ or more. By employing this classification rule, agreement with the classification based on the findings of microbiological assay of isoniazid was obtained in 101 of 102 patients. The single discrepancy (a rapid inactivator with a value of $65 \%$ ) appears to be due to a misclassification by the urine sulphadimidine test method, as the classification by the microbiological assay of isoniazid was confirmed in this instance by the classification based on the percentage of acetylated sulphadimidine in blood (see above).

Stability of Sulphadimidine in Urine.-From each of four subjects (three slow inactivators and one rapid inactivator) a specimen of urine was collected at six hours after a dose of sulphadimidine. Aliquots of each specimen were stored for nine days at $37^{\circ} \mathrm{C}$., room temperature $\left(27^{\circ}-30^{\circ} \mathrm{C}\right.$.), and at $4^{\circ} \mathrm{C}$., in each case with and without the addition of thymol as a preservative. There was no evidence of change in the content of free or total sulphadimidine under any of these conditions of storage (data not presented here).

\section{Discussion}

Highly satisfactory agreement has been found between the results obtained from a well-established procedure for classifying patients as slow or rapid inactivators of isoniazid (microbiological assay of isoniazid in serum, employing a vertical diffusion method), and from the procedures described in this paper, which are based on estimations of acetylated sulphadimidine in blood and in urine after an oral dose of sulphadimidine. Thus only $3 \%$ of our patients were misclassified by the blood sulphadimidine test and $1 \%$ by the urine sulphadimidine test. These results confirm the observations made by Evans and White (1964) and Peters, Gordon, and
Brown (1965), in small groups of volunteers and patients, of parallelism between isoniazid inactivation rate and sulphadimidine acetylation rate.

The advantages of the sulphadimidine acetylation test are, firstly, the method of estimation is simple, requiring only a colorimeter or a visible range spectrophotometer, whereas chemical methods for the estimation of isoniazid require extraction procedures with organic solvents and estimation with an ultraviolet spectrophotometer or a fluorimeter. Secondly, the results are available on the same day, whereas a microbiological assay of isionazid takes about two weeks. Thirdly, specimens do not require cold storage, since, unlike free isoniazid, sulphadimidine and its acetyl derivative are heat stable.

Evans (1969) observed that the percentage of acetylated sulphadimidine in serum appeared to be a better phenotypic discriminant than the same constituent in urine. In the prešnt study, however, the urine test was slightly more efficient than the blood test in discriminating between slow and rapid inactivators of isoniazid, the measure of discrimination ( $t$ value) being 20.5 for the urine test and 15.2 for the blood test (see Chart). Further, it is easier to obtain urine specimens than blood specimens from patients; in practice, therefore, the urine sulphadimidine test is preferable to the blood test.

We are indebted to the physicians and nursing staff of the Centre for organizing the collection of the specimens, to Miss $\mathrm{K}$. Alamelu for technical assistance, and to Dr. N. K. Menon for help in the preparation of the paper.

Requests for reprints should be addressed to Director, Tuberculosis Chemotherapy Centre, Madras 31, India.

The Tuberculosis Chemotherapy Centre is under the joint auspices of the Indian Council of Medical Research, the Tamil Nadu (Madras State) Government, and the World Health Organization in collaboration with the Medical Research Council of Great Britain.

\section{REFERENCES}

Eidus, L., and Hamilton, E. J. (1964). American Review of Respiratory Diseases, 89, 587.

Evans, D. A. P. (1965). Annals of the New York Academy of Sciences, 123, 178

Evans, D. A. P. (1969). Fournal of Medical Genetics, 6, 405.

Evans, D. A. P., Manley, K. A., and McKusick, V. A. (1960). British Medical fournal, $2,485$.

Evans, D. A. P., and White, T. A. (1964). Fournal of Laboratory and Clinical Medicine, 63, 394.

Harris, H. W. (1959). In Transactions of the Eighteenth Conference on the Chemotherapy of Tuberculosis, p. 70. Washington, Veterans Administration.

Harris, H. W. (1961). In Transactions of the Twentieth Research Conference in Pulmonary Diseases, p. 39. Washington, Veterans Administration.

Jenne, J. W. (1960). American Review of Respiratory Diseases, 81, 1.

Jenne, J. W. (1961). American Review of Respiratory Diseases, 83, 906.

Knight, R. A., Selin, M. J., and Harris, H. W. (1959). In Transactions of the Eighteenth Conference on the Chemotherapy of Tuberculosis, p. 52 Washington, Veterans Administration.

Lloyd, J., and Mitchison, D. A. (1964). Fournal of Clinical Pathology, 17, 622. Menon, N. K. (1968). Bulletin of the International Union Against Tuberculosis, 41, 316.

Peters, J. H., Gordon, G. R., and Brown, P. (1965). Life Science, 4, 99.

Peters, J. H., Miller, K. S., and Brown, P. (1965). Fournal of Pharmacology and Experimental Therapeutics, 150, 298.

Poole, F., and Meyer, A. E. (1960). Proceedings of the Society for Experimental Biology and Medicine, 104, 560 .

Schmidt, L. H. (1962). Bulletin of the International Union Against Tuberculosis, 32, 487 .

Scottish Thoracic Society (1962). Tubercle, 43, 139.

Selkon, J. B., et al. (1961). Bulletin of the World Health Organization, $25,779$. Sunahara, S., Urano, M., and Ogawa, M. (1961). Science, 134, 1530.

Tuberculosis Chemotherapy Centre, Madras (1963). Bulletin of the World Health Organization, 29, 457.

Tuberculosis Chemotherapy Centre, Madras (1970). Bulletin of the World Health Organization (in press).

Varley, H. (1962). Practical Clinical Biochemistry, 3rd ed., p. 634. London, Heinemann. 